\title{
Pengaruh Penerapan Anggaran Berbasis Kinerja Terhadap Kinerja SKPD Pemerintah di Kabupaten Kepulauan Sangihe
}

\author{
Deifi Sari Maindoka \\ Heince.Wokas
}

\begin{abstract}
Budget is needed to reveal what it will doin the future. Budgets are usually only focused for a certain period or a period of lyear. With a good budget, can be easily obtained information in decision-making. Therefore, it is necessary to havean effective budget allocation to balance the various demands in achieving the desired objectives.

The objectives of this research was todetermine the effect of the application of performance-based budgeting to performance work unit in the islands of Sangihe regency government. The research was done by conducting a survey to the Echelon II and Echelon III and data collection is done by distributing questionnaires to 60 respondents.

The analytical method used is simple line arregression analysis, and hypothesis testing is used for testing statisticalt-test. With the help of a computer software program SPSS Version 2.0 for windows. Simple line arregression analysis results obtaine dequation $Y=5,134+0.748 X$. coefficient for variable $X$ (Performance-based budgeting)) is equal to the positive (0.748), this means that the variable performance-based budgeting or direct positive effecton the variable $Y$ (Performance on education). The contribution of performance-based budgeting to the rise and fall of variation of performance variables on education goverment in Sangihe regency indicated by the coefficient of determination of $57.3 \%$ while the remaining $43.7 \%$ is explained by other factors not examined in this study include reporting information system finance.
\end{abstract}

Key Word: Performance-based budgeting, Performance on education 


\section{PENDAHULUAN}

\subsection{Alasan Pemilihan Judul}

Mengacu pada undang-undang Nomor 32 tahun 2004 tentang pemerintah daerah dan undangundang Tahun 33 tahun 2004 tentang perimbangan antar keuangan pusat dan daerah tersebut dalam mengukur pengelolaan keuangan daerah, pemerintah melalui Menteri Dalam Negeri mengeluarkan dan memberlakukan suatu keputusan menyangkut keuangan daerah, yang disebut peraturan Menteri Dalam Negeri Nomor 26 Tahun Anggaran 2007. Dengan adanya peraturan Menteri Dalam Negeri Nomor 26 Tahun 2006, daerah dapat lebih memperhatikan akuntabilitas, konsistensi, akurat, dapat dipercaya dan mudah dimegerti dalam penyusunan APBD.

Sebelum berlakunya anggaran berbasis kinerja, metode penganggaran yang digunakan adalah metode tradisional atau item line budget. Cara penyusunan anggaran ini tidak didasarkan pada analisa rangkaian kegiatan yang harus dihubungkan dengan tujuan yang telah ditentukan, namun lebih dititikberatkan pada kebutuhan untuk belanja/pengeluaran dan sistem pertanggung jawabannya tidak diperiksa dan diteliti apakah dana tersebut telah digunakan secara efektif dan efisien atau tidak. Tolok ukur keberhasilan hanya ditunjukan dengan adanya keseimbangan anggaran antara pendapatan dan belanja dan dalam perkembangannya, muncullah sistematika anggaran kinerja yang diartikan sebagai suatu bentuk anggaran yang sumber-sumbernya dihubungkan dengan hasil dari pelayanan.

Pengelolaan keuangan daerah menetapkan kepala satuan kerja pengelolaan keuangan daerah sebagai bendahara umum daerah, maka fungsi pembendaharaan akan dipusatkan di satuan kerja pengelolaan keuangan daerah. Namun demikian untuk menyelesaikan proses pembayaran yang bernilai kecil dibentuk kas kecil pada satuan kerja pengguna anggaran yang dilakukan oleh bendahara pengeluaran.

Kepala satuan kerja perangkat daerah selaku penjabat pengguna anggaran dalam melaksanakan tugas berdasarkan pertimbangan tingkat daerah, besaran SKPD, besaran jumlah uang yang dikelolah, lokasi, kompetensi dan /atau tentang kendali dan pertimbangan objektif lainnya dapat melimpahkan sebagai kewenangannya kepala unit kerja SKPD selaku kuasa pengguna anggaran/pengguna barang. Pelimpahan wewenang sebagaimana yang dimaksud ditetapkan oleh kepala daerah atas usul kepala SKPD. Kuasa pengguna anggaran adalah pejabat yang diberi kuasa untuk melaksanakan sebagian kewenangan pengguna anggaran dalam melkasanakan sebagian tugas dan fungsi SKPD.

Kabupaten Kepulauan Sangihe dituntut untuk mengutamakan upaya pencapaian hasil kerja untuk mencapai pendekatan berbasis kinerja dan juga dengan memperhatikan keterkaitan antara pendanaan dengan keluaran dan hasil yang diharapkan dari kegiatan dan program termasuk efisien dalam pencapaian keluaran dan hasil tersebut. Manfaat anggaran berbasis kinerja mengandung makna bahwa setiap penyelenggara pemerintah berkewajiban untuk bertanggung jawab atas hasil proses dan penggunaan sumber dayanya.

Dalam rangka penerapan anggaran berbasis kinerja setiap komponen pelayanan pada masingmasing urusan pemerintah yang diselenggarakan oleh SKPD dalam rangka penilaian kinerja, harus ditetapkan oleh masing-masing daerah. Dalam pelaksanaan program kegiatan yang dilaksanakan setiap SKPD di Kabupaten Kepulauan Sangihe masih belum maksimal, baik dalam penerapan maupun pelaksanaan. Penerapan Anggaran berbasis kinerja sangat penting dilakukan karena dengan adanya sistem anggaran berbasis kinerja dapat mengukur bagaimana kinerja yang dihasilkan. Dalam pelakasanaan suatu kegiatan evaluasi kinerja dengan menggunakan prinsip anggaran berbasis kinerja yaitu ekonomis, efisiensi dan efektivitas belum sepenuhnya dilaksanakan oleh pemerintah daerah, karena ekonomis dan efisiensi terkait dengan pelaksanaan suatu kegiatan sedangkan, efektivitas akan selalu terkait dengan pelaksanaan suatu program.

Dasar ini yang menjadikan penulis ingin melakukan penelitian terhadap Kinerja Pemerintah yang ada di Kabupaten Kepulauan Sangihe penulis membahasnya dalam laporan akhir yang berjudul "Pengaruh penerapan Anggaran Berbasis Kinerja terhadap Kinerja SKPD di Pemerintah Kabupaten kepulauan Sangihe". 
Populasi dalam penelitian ini adalah 153 orang pejabat eselon dua dan eselon tiga di SKPD pada Pemerintah Kabupaten Kepulauan Sangihe.

Sampel adalah sebagian dari jumlah dan karakteristik yang dimilki oleh populasi tersebut. Jumlah populasi sebanyak 153, jumlah minimum sampel yang dibutuhkan sebanyak 60, Kuesioner yang disebarkan adalah sebanyak 60 kuesioner dan yang kembali adalah 60 kuesioner.

\section{LANDASAN TEORI}

\subsection{Anggaran Secara Umum}

"National Commite On Govermental Accounting (NCGA)" Atau yang saat ini "Govermental Accounting Standar Boards" mendefinisikan anggaran sebagai berikut, yaitu rencana operasi keuangan yang mencangkup estimasi pengeluaran yang diusulkan, dan sumber pendapatan yang diharapkan untuk membiayainya dalam periode waktu tertentu.

Anggaran pemerintah adalah jenis rencana yang menggambarkan rangkaian tindakan atau kegiatan yang dinyatakan dalam bentuk angka-angka rupiah untuk suatu jangka waktu tertentu. Anggaran pemerintah merupakan pedoman bagi segala tindakan yang akan dilaksanakan dan didalam anggaran disajikan rencana-rencana penerimaan dan sistemaris.

\subsection{Anggaran Berbasis Kinerja}

Sebelum berlakunya sistem Anggaran Berbasis Kinerja, metode penganggaran yang digunakan adalah metode tradisional atau item line budget. Cara penyusunan anggaran ini tidak didasarkan pada analisa rangkaian kegiatan yang harus dihubungkan dengan tujuan yang telah ditentukan, namun lebih dititikberatkan pada kebutuhan untuk belanja/pengeluaran dan sistem pertanggung jawabannya tidak diperiksa dan diteliti apakah dana tersebut telah digunakan secara efektif dan efisien atau tidak.

Anggaran kinerja mencerminkan beberapa hal. Pertama, maksud dan tujuan permintaan dana. Kedua, biaya dari program-program yang diusulkan dalam mencapai tujuan ini. Dan yang ketiga, data kuantitatif yang dapat mengukur pencapaian serta pekerjaan yang dilaksanakan untuk tiap-tiap program. Penganggaran dengan pendekatan kinerja ini berfokus pada efisiensi penyelenggaraan suatu aktivitas.

\subsection{Kinerja SKPD}

Kinerja mengacu pada suatu hasil yang dicapai atas kerja atau kegiatan yang telah dilakukan.

Dalam konteks pemerintahan, kinerja akan dinilai sebagai suatu prestasi manakala dalam melaksanakan suatu kegiatan dilakukan dengan mendasarkan pada peraturan yang berlaku, tidak melnggar hukum atau tidak sesuai moran dan etika.

\subsection{Laporan Keuangan}

Menurut Erlina (2008:18) dikutip dari Hartina (2009), Laporan Keuangan adalah produk akhir dari proses akuntansi yang telah dilakukan. Laporan keuangan yang telah disusun harus memenuhi prinsip-prinsip yang dinyatakan dalam PP No. 24 Tahun 2005. Laporan keuangan daerah suatu hasil dari proses pengidentifikasian, pengukuran, pencatatan dari transaksi ekonomi dari entitas pemerintah daerah yang dijadikan informasi dalam rangka pertanggungjawaban pengelolaan keuangan daerah dan pengambilan keputusan ekonomi oleh pihak-pihak eksternal entitas pemerintah daerah yang memerlukannya.

\section{GAMBARAN UMUM OBJEK PENELITIAN}

\subsection{Gambaran Umum Kabupaten Kepulauan Sangihe}

Kabupaten Kepulauan Sangihe merupakan bagian integral dari Propinsi Sulawesi Utara,

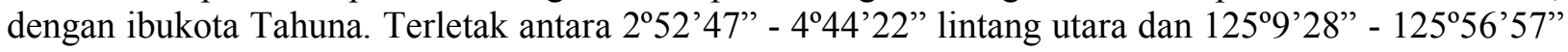
bujur timur berada diantara Pulau Sulawesi dan Pulau Mindanao (Republik Filipina) sehingga Kabupaten Kepulauan Sangihe disebut Daerah Perbatasan. Bagian utara berbatasan dengan Republik Filipina, bagian timur berbatasan dengan Kabupaten Talaud dan laut Maluku, sebelah selatan berbatasan dengan Kabupaten Sitaro dan bagian barat berbatasan dengan laut Sulawesi. 


\section{PEMBAHASAN}

\subsection{Analisis Regresi Linear Sederhana}

Berdasarkan hasil perhitungan data dengan menggunakan bantuan program SPSS, maka hasil perhitungan analisis regresi linear sederhana dapat dilihat dalam Tabel 4.4 berikut:

\section{Tabel 4.5}

\section{Coefficients $^{\mathrm{a}}$}

\begin{tabular}{|c|c|c|c|c|c|}
\hline \multirow[t]{2}{*}{ Model } & \multicolumn{2}{|c|}{$\begin{array}{c}\text { Unstandardized } \\
\text { Coefficients }\end{array}$} & $\begin{array}{l}\text { Standardized } \\
\text { Coefficients }\end{array}$ & \multirow[t]{2}{*}{$\mathrm{T}$} & \multirow[t]{2}{*}{ Sig. } \\
\hline & B & Std. Error & Beta & & \\
\hline (Constant) & 5.134 & 1.485 & & 3.457 & .001 \\
\hline ABK & .748 & .083 & .762 & 8.953 & .000 \\
\hline
\end{tabular}

a. Dependent Variable: KINERJA SKPD

Sumber : Hasil Olahan Data 2012

Dari Tabel 4.5 di atas, maka dapat diketahui bahwa model regresi yang diperoleh adalah :

$$
Y=5.134+0.748 X
$$

Persamaan tersebut dapat dijelaskan sebagai berikut.

3. Konstanta $\boldsymbol{\alpha}$ sebesar 5.134 mempunyai arti bahwa jika Penerapan Anggaran Berbasis Kinerja atau sama dengan nol (0), maka besarnya variabel Kinerja Satuan Kerja Perangkat Daerah (Y) sebesar 5.134.

4. Nilai $\beta_{1}$ yang merupakan koefisien regresi dari variabel $\mathrm{X}_{1}$ (Penerapan anggaran berbasis kinerja) sebesar 0.748 mempunyai arti bahwa jika variabel Penerapan anggaran berbasis kinerja mengalami peningkatan 1\% maka besarnya variabel Kinerja Satuan Kerja Perangkat Daerah (Y) juga akan ikut mengalami kenaikan atau peningkatan sebesar 0.748 .

Dengan demikian dapat diketahui bahwa terdapat hubungan antara variabel bebas $\mathrm{X}$ dengan variabel terikat $\mathrm{Y}$, dimana angka koefisien regresi yang diperoleh semuanya menunjukan angka positif $(+)$. Ini berarti variabel anggaran berbasis kinerja memiliki pengaruh positif atau searah terhadap variabel kinerja SKPD, Jika nilai X meningkat maka $\mathrm{Y}$ meningkat sebaliknya jika nilai $\mathrm{X}$ turun maka $\mathrm{Y}$ juga turun.

\subsection{Pengujian Hipotesis}

Perumusan hipotesis yang diuji, telah dikemukakan pada Bab sebelumnya dengan tingkat signifikansi yang digunakan dalam penelitian ini sebesar $5 \%$ atau $\alpha=0,05$ maka hasil pengujian hipotesis tersebut adalah sebagai berikut :

Uji t

Uji t digunakan untuk menguji signifikansi pengaruh variabel independen terhadap variabel dependen dalam model regresi yang sudah dihasilkan. Maka digunakan uji t untuk menguji masingmasing variabel independen terhadap variabel dependen.

Dengan menggunakan bantuan program SPSS maka hasil uji t daat dilihat pada Tabel 4.5 Untuk variabel $b_{1}$ anggaran berbasis kinerja $\left(\mathrm{X}_{1}\right)=8.953$ dengan nilai probabilitas signifikan sebesar 0,000 . Karena probabilitas signifikan lebih kecil dari 0,05 dapat disimpulkan bahwa hipotesis ini diterima. Hal ini menjelaskan tentang pengaruh positif antara variabel anggaran berbasis kinerja terhadap kinerja SKPD.

\subsection{Pembahasan}

\subsubsection{Pengaruh penerapan anggaran berbasis kinerja terhadap kinerja SKPD}

Hasil pengujian hipotesis menunjukkan bahwa pengaruh penerapan anggaran berbasis kinerja terhadap kinerja Satuan Kerja Perangkat Daerah berpengaruh positif sebesar 8,953 pada tingkat signifikansi 0.000 , yang berarti signifikan karena berada di bawah nilai signifikan yang dipersyaratkan 
yaitu 0.05, sehingga dapat disimpulkan bahwa anggaran berbasis kinerja dapat meningkatkan kinerja Satuan Kerja Perangkat Daerah.

Hasil pengujian hipotesis ini menyatakan bahwa penerapan anggaran berbasis kinerja berpengaruh positif dan signifikan terhadap kinerja Satuan Kerja Perangkat Daerah. Hal ini mengindikasikan bahwa prinsip dari anggaran berbasis kinerja perlu dilaksanakan serta penyusunan anggaran hendaknya dilakukan berlandaskan azas efisiensi, tepat guna, tepat waktu pelaksanaan, dan penggunaannya dapat dipertanggungjawabkan. Dana yang tersedia harus dimanfaatkan dengan sebaik mungkin untuk dapat menghasilkan peningkatan dan kesejahteraan yang maksimal. Hasil pengujian untuk variabel anggaran berbasis kinerja menunjukkan bahwa variabel anggaran berbasis kinerja berpengaruh terhadap Kinerja SKPD. Dalam penganggaran dengan pendekatan kinerja ini disusun dengan orientasi output. Jadi, apabila kita menyusun anggaran dengan pendekatan kinerja, maka mindset kita harus fokus pada apa yang ingin dicapai. Kalau fokus ke output, berarti pemikiran tentang tujuan kegiatan harus sudah tercakup di setiap langkah ketika menyusun anggaran. Dengan demikian apabila pelaksanaan anggaran berjalan dengan baik berdasarkan anggaran berbasis kinerja, output dan feedback maka akan menghasilkan output/outcome serta kinerja yang baik.. Hal ini konsisten dengan penelitian terdahulu oleh Syahputra (2010) yang menyatakan bahwa anggaran berbasis kinerja berpengaruh terhadap kinerja SKPD.

Penyusunan anggaran berbasis kinerja dilakukan berdasarkan capaian kerja. Capaian kerja adalah ukuran prestasi kerja yang akan dicapai dari keadaan semula dengan pertimbangan faktor ekonomi, efisiensi, dan efektivitas pelaksanaan dari setiap program dan kegiatan.

\section{PENUTUP}

\subsection{Kesimpulan}

Berdasarkan hasil analisis data dan pengujian hipotesis dengan menggunakan alat bantu SPSS yang telah diuraikan pada bab sebelumnya, maka diperoleh kesimpulan mengenai penerapan anggaran berbasis kinerja adalah anggaran berbasis kinerja berpengaruh secara signifikan terhadap kinerja satuan kerja perangkat daerah. Hal ini menunjukan apabila pelaksanaan anggaran berjalan dengan baik berdasarkan anggaran berbasis kinerja, output dan feedback maka akan menghasilkan output/outcome serta kinerja yang baik.

\subsection{Saran}

1. Di Pemerintah Kabupaten Sangihe prinsip dari anggaran berbasis kinerja perlu dilaksanakan serta Penyusunan anggaran hendaknya dilakukan berlandaskan azas efisiensi, tepat guna, tepat waktu pelaksanaan, dan penggunaannya dapat dipertanggungjawabkan. Dana yang tersedia harus dimanfaatkan dengan sebaik mungkin untuk dapat menghasilkan peningkatan dan kesejahteraan yang maksimal.

2. Bagi penelitian selanjutnya, sebaiknya menggunakan sampel yang lebih besar dan mencakup pada seluruh pengelola keuangan daerah serta bisa menambah variabel-variabel yang lain yang dapat meningkatkan kinerja SKPD.

\section{DAFTAR PUSTAKA}

Brownel, P. dan McInnes M. 1986. "Budgetary Participation, Motivation, and Managerial Performance”, The Accounting Review, Vol. LXI, No. 4. Milani, K. 1975. "The Relationship of Participation in Budget-Setting to Industrial Supervisor Performance and Attitudes : A Field Study”, The Accounting Review 50.

Darise Nurlan (2009), Pengelolaan Keuangan Daerah, Buku Edisis 2, Gorontalo.

Ismail dan Rahim. 2009. Pengelolaan Keuangan pada Satuan Kerja Perangkat Daerah dan BLU, Edisi Kedua, Gorontalo.

Mahsun, Mohamad. 2009. Pengukuran Kinerja sektor Publik. Yogyakarta : BPFE

Mardiasmo. 2005. Akuntansi Sektor Publik. Yokyakarta : Penerbit Andi. 
Matheos,2009. "Pengaruh Karakteristik Tujuan Anggaran Terhadap Kinerja Aparat Pemerintah Manado."

Poae, 2011. "Pengaruh Komitmen Organisasional dan Peran Manajer Pengelolaan Keuangan Daerah terhadap Kinerja Manajerial Satuan Kerja Perangkat Daerah di Kabupaten Kepulauan Talaud."

Putra,2010. "Pengaruh Penerapan Anggaran Berbasis Kinerja Dan Sistem Informasi Pengelolaan Keuangan Daerah terhadap Kinerja SKPD di Pemerintah Kabupaten Simalungu."

Republik Indonesia,2003. Undang-undang Republik Indonesia Nomor 17 tahun 2003 tentang keuangan Negara.

Republik Indonesia,2004. Undang- undang Republik Indonesia Nomor 33 tahun 2004 tentang Perimangan Keuangan Antara Pemerinah Pusat dan Pemerintah Daerah.

Republik Indonesia,2005. Peraturan Pemerintah Republik Indonesia nomor 58 tahun 2005 tentang Pengelolaan Keuangan Daerah.

Republik Indonesia,2006. Peraturan Pemerintah Republik Indonesia nomor 26 tahun 2005 tentangPedoman Penyususnan Anggaran Pendapatan dan Belanja Daerah Tahun Anggaran 2007.

Rohman, A. 2009. Akuntansi Sektor Publik Telaah dari Dimensi : Pengelolaan Keuangan Daerah, Good Governance, Pengendalian, Pengawasan dan Pengukuran Kinerja Pemerintah Daerah. Semarang: Badan Penerbit Universitas Diponegoro.

Sabeni dan Ghozali, 2008. Akuntansi Pemerintahan. Edisi 4, Semarang

Setyarto, A. 2008. "Pengaruh Gaya Kepemimpinan, Profesionalisme, Komitmen Organisasi, Dan Kepuasan Kerja Terhadap Kinerja Karyawan Bagian Akuntansi (Survey Pada Koperasi Simpan Pinjam Di Wilayah Kota Madya Surakarta)." Skripsi Tidak Dipublikasikan, Universitas Muhammadiyah Surakarta

Tawera, 2011. "Penerapan Anggaran Berbasis Kinerja dan Sistem Informasi Pengelolaan Keuangan Daerah terhadap Kinerja SKPD di Pemerintah Kota Kotamobagu”

Tuasikal, A. 2007. "Pengaruh Pemahaman Sistem Akuntansi, Pengelolaan Keuangan Daerah Terhadap Kinerja Satuan Kerja Pemerintah Daerah (Studi pada Kabupaten Maluku Tengah di Provinsi Maluku).” Jurnal Akuntansi Dan Keuangan Sektor Publik, Vol. 08, No. 01, pp.1466148

http://www.kabupatensangihe.go.id

http://www.anggaran berbasis kinerja.html

http://satuan kerja perangkat daerah kabupatensangihe.com

http://www.pengertian akuntansi pemerintah.go.id 